\title{
Nutrition in Stoma Patients: A Practical View of Dietary Therapy
}

\author{
Gamze AKBULUT \\ Gazi University Faculty of Health Sciences, Department of Nutrition Dietetics, Ankara, TURKEY
}

\begin{abstract}
This article reviews the various issues that surround the dietary planning for a patient with stoma (colostomy, ileostomy, and urostomy). The ostomy diet is necessary to keep stools normal following surgery, since the amount, frequency and consistency of stool is influenced by the diet. The goals of dietary management in stoma patients is to prevent stoma blockages after surgery, to promote healing of stoma wound and to minimise unpleasant gastrointestinal upset such as flatulence, diarrhoea, constipation and odors. On the other hand, early oral feeding in patients with colostomy is important. Since it is planned to progress from a liquid to low fiber (residue) diet. Some foods may not be as well tolerated and may cause flatulence, odors, diarrhea and/or constipation. Preoperatively, fiber and lactose intolerances are common in ileostomy patients. Postoperatively, it is important to provide a high-energy, high-protein diet for wound healing that is low in excess insoluble fiber. Certain foods and drugs can discolor the urine or produce a strong odor. In order to recognize the signs of food blockage, it is suggested to take plenty of fluids and consume a balanced diet in stoma patients.
\end{abstract}

Keywords: Surgical stoma, Colostomy, lleostomy, Urostomy, Diet therapy

\section{ÖZET}

\section{Stomalı Hastalarda Beslenme: Diyet Tedavisine Pratik Bir Bakış}

Bu makale, stomalı bir hastanın (kolostomi, ileostomi ve ürostomi) diyet tedavisinin planlanmasına yönelik çeşitli bölümleri içermektedir. Dışkı miktarı, sıkığı ve kıvamının diyet tüketiminden etkilenmesi nedeniyle, cerrahi sonrası normal dışkılamanın sağlanmasında ostomi diyetinin uygulanması gerekmektedir. Stomalı hastalarda diyet tedavisinin amaçlarına bakıldığında; ameliyat sonrası stoma tıkanıkıklarıı önlemek, açılan stomadaki yara iyileşmesine katkıda bulunmak, gaz, diyare, konstipasyon, koku gibi rahatsızlık veren gastrointestinal semptomları en az indirgemektir. Buna ek olarak, kolostomili hastalarda erken oral beslenme önemlidir. Sıvı diyetten düşük posalı (kalıntılı) diyete geçiş planlanmaktadır. Bazı besinler iyi tolere edilemediğinden gaz, kötü koku, diyare ve/veya konstipasyona neden olabilir. Illeostomili hastalarda operasyon öncesinde, posa ve laktoz intoleransı sıklikla görülmektedir. Operasyon sonrasında ise; çözünmez posa içeriği düşük, yüksek-enerji ve yüksekprotein içeren diyetin yara iyileşmesini hızlandırması açısından önemlidir. Bazı besinler ve ilaçlar idrar renginde değişikliğe ve güçlü bir koku üretimine neden olmaktadır. Stomalı hastalarda gıda blokajını fark edebilmek için bol sıvı alımının ve dengeli bir diyet tüketiminin sağlanması önemlidir.

Anahtar Kelimeler: Cerrahi stoma, Kolostomi, Ileostomi, Ürostomi, Diyet tedavisi 


\section{INTRODUCTION}

A stoma is a Greek word meaning "mouth or opening". Dietary advice is an important aspect of patients with stoma. The ostomy diet is necessary to keep stools normal following surgery, since the amount, frequency and consistency of stool is influenced by the diet. It is important for healthcare professionals involved in the care of patients with a colostomy, ileostomy or urostomy to appreciate that stoma surgery changes the body's usual processes of nutritional absorption and excretion; so that informed support and advice on diet can be provided. Patients undergoing gastrointestinal surgery resulting in stoma formation are at particular risk as a result of the potential for preoperative malnutrition caused by the effects of their underlying disease and prolonged periods of fasting during the immediate pre- and postoperative period. Screening and monitoring of the nutritional status of individuals with a stoma should be an ongoing process, beginning preoperatively and continuing after discharge from hospital. ${ }^{2}$

This guide provides some basic information about the effects of ostomy surgery has on digestion and food absorption. After healing is complete and the ostomy is functioning normally, most people with ostomies can return to a normal diet. ${ }^{3}$

The literature is discussed below in the following headings:

- Type of ostomies

- Dietary therapy of common ostomies

- General healthy eating guidelines in stoma

\section{TYPE OF OSTOMIES}

\subsection{Bowel Diversions}

a. Colostomy: A portion of the large intestine is removed or by-passed. The remaining portion of the functioning large intestine (colon) is brought through the abdominal wall, creating a stoma.

b. Ileostomy: The entire colon, rectum, and anus are removed or by-passed. The small intestine (ileum) is brought through the abdominal wall, creating a stoma.

c. Continent Ileostomy (abdominal pouch): An internal reservoir with a nipple valve is constructed from a section of small intestine and the valve is brought through the abdominal wall to create a stoma for intubation to empty the reservoir/pouch.

d. Ileoanal Reservoir/Pelvic Pouch: A pelvic pouch/reservoir is constructed from small intestine, which is brought down and attached to the anus. Evacuation is through the anus.

\subsection{Bladder Diversions}

a. Urostomy: The bladder is removed or bypassed. A conduit is constructed from a segment of small intestine into which ureters are implanted and brought through the abdominal wall and an external stoma is created.

b. Continent Urinary Reservoir: The bladder is removed or bypassed. An internal reservoir is constructed from a segment of the small or large intestine into which the ureters are implanted and a stoma is created for intubation to empty the reservoir/pouch. ${ }^{4,5}$

\section{DIETARY THERAPY OF COMMON OSTOMIES}

\subsection{The aims of dietary management:}

a. Prevent stoma blockages after surgery

b. Promote healing of stoma wound

c. Minimise unpleasant gastrointestinal upset such as flatulence, diarrhoea, constipation and odors. ${ }^{6}$

a. Colostomy: Early oral feeding in the patients undergoing is feasible, safe, and associated with reduced post-operative discomport; it can accelerate the return of bowel function and improve rehabilitation. It is planned to progress from a liquid to low residue diet. To speed healing, the formula or diet should also be high in protein, energy, vitamins, and minerals. Diet should provide normal or increased salt intake. One to two quarts of fluid, taken between meals, should be ingested daily. Gradually introduce new foods; if done slowly, offending foods can be indentified and obstruction can be controlled or prevented. ${ }^{7-9}$

Some foods may not be as well tolerated and may cause flatulence (gas), odors, diarrhea and/or constipation. Table 1 shows a food chart of common food which may cause intolerance. ${ }^{10-12}$ Food can also be used to help alleviate intolerance. Table 2 shows a chart that lists food which may help. ${ }^{10-12}$ 
Table 1. Food Chart-Troubleshooting-I

\begin{tabular}{|llll|}
\hline Stoma Obstructive & Oddor Producing & $\begin{array}{l}\text { Increased/Loose } \\
\text { Stool-Diarrhoea }\end{array}$ & Gas Producing \\
\hline Apple Peels & Asparagus & Alcoholic beverage & Alcoholic beverage \\
Raw cabbage & Baked beans & Whole grains & Carbonated drink \\
Celery & Broccoli & Bran cereals & Beans \\
Chinese vegetables & Cabbage & Cooked cabbage & Soy \\
Corn, whole kernels & Cod Liver Oil & Fresh fruits & Cabbage \\
Coconuts & Eggs & Green, leafy & Cauliflower \\
Dried fruit & Fish & Milk & Cucumbers \\
Mushrooms & Garlic & Prunes & Dairy products \\
Oranges & Onions & Apple and Prune juice & Chewing gum \\
Nuts & Peanut butter & Raisins & Milk \\
Pineapple & Some vitamins & Raw vegetables & Nuts \\
Popcorn & Strong chees & Spices & Onions \\
Fruits with skin\& seeds & & & Radishes \\
\hline
\end{tabular}

Floruta et al. ${ }^{13}$ has found that the majority of patients in their study (88.4\%) stated that they were not following a special diet because of the ostomy; $11.8 \%(n=69)$ stated that they had modified their diet. Of the people who had modified their diet, $55 \%$ stated that they were using the special diet indefinitely and were adhering to it very well. More than half of the participants had received dietary instructions, provided mainly by a WOC nurse, at the time of surgery. The foods avoided because of the ostomy included fresh fruits, nuts, coconut, and vegetables such as corn, popcorn, cabbage, beans, and onions. The major problems reported were blockage and increased gas.

b. Ileostomy: The entire large intestine, rectum and anus are not used temporarily. This is to rest the whole system to allow healing to take place before joining them back together again. The small intestine (ileum) is brought to the abdominal wall to form a stoma for defeacation. This procedure causes a decrease in fat, bile acid, and vitamin $\mathrm{B}_{12} \mathrm{ab}$ sorption, as well as greater losses of sodium and potassium..$^{14}$

The nutritional requirements will vary based on the bowel which have been remaining, the health of the remaining bowel, the overall health and other conditions or diagnoses. All individuals with ostomies have lost a portion of their bowel and will need to compensate by optimizing their diet for the nutrients in question..$^{15}$

Preoperatively, fiber and lactose intolerances are common in ileostomy patients. With strictures, the patients should avoid popcorn, nuts, seeds, mushrooms, celery, fruit skins, and vegetable skins, and chew thoroughly. Postoperatively, it is important to provide a high-energy, high-protein diet for wound healing that is low in excess insoluble fiber. The high-fiber foods are suggested to avoid for preoperative care for about 4 weeks. Pectin in apples and oligosaccharides in oatmeal may be beneficial to add back first. Spinach or parsley are natural intestinal deodorizers, but beware of excesses of oxalate-rich foods. The patient needs an adequate intake of protein (provided by low-fat sources such as lean meats and egg white), vitamin B12 (provided by liver, fish, eggs), folic acid, calcium, magnesium, iron, sodium, vitamin $\mathrm{C}$, and potassium. Diet should provide an adequate amount of fluids, especially in hot water. Since obesity can cause more discomfort, a long-range weight management plan may be useful..$^{16,17}$

The goal of the dietary approach in ileostomy patients is to provide a step-wise management of care. We have to determine the location of an amount of 
Table 2. Food Chart-Troubleshooting- ॥

\begin{tabular}{|llll|}
\hline Constipation Relief & Odor Control & Loose stool control & Reducing Flatus \\
\hline Coffee, warm/hot & Buttermilk & Apple sauce & Fennel tea \\
Cooked fruits & Cranberry juice & Unripe bananas & Cranberry juice \\
Cooked vegetables & Orange juice & Boiled rice & Buttermilk \\
Fresh fruits & Parsley & Peanut butter & Peppermint oil \\
Fruit juices & Tomato juice & Tapioca & \\
Water & Yoghurt & Toast & Colour Changes \\
Mild laxative & Peppermint oil & White bread & Asparagus \\
& & Potatoes & Beets \\
& & Pasta & Food colours \\
& & Crackers & Iron pills \\
& & Boiled rice & Licorice \\
& & Weak tea & Strawberries \\
& & Marshmallows & Tomato sauces \\
\hline
\end{tabular}

the intestine that was resected to predict likelihood of diarrhea, malabsorption, and malnutrition. The diet should provide nutrient replacements, dependent on the area of resection (proximal jejunumcalcium, iron, magnesium, protein, carbohydrate, and fat; terminal ileum- bile acids and intrinsic factor-bound vitamin $\left.\mathrm{B}_{12}\right)$. $^{18,19}$

\section{Managing the three phases in ileostomy patients after surgery:}

First Postoperative Phase: 1-3 months, massive diarrhea and limited absorption

Intravenous (IV) nutrition or total paranteral nutrition (TPN) may be appoopriate immediately before and approximately 5 days after surgery to allow rest. Determine whether the patient has problems with bloating. The first phase involves extensive diarrhea greater than 2 L/daily; TPN ise used, advancing slowly to avoid refeeding syndrome. At the end of this time, if diarrhea continues to be greater than $2 \mathrm{~L}$, TPN may be lifelong. ${ }^{17}$

Second Postoperative Phase: 4-12 months, weight gain begins and absorption improves.

Diarrhea is lessened and intestinal adaptation begins; TPN may be slowly reduced and tube feeding (TF) started at a slow, continuous rate according to stomal output or stool output. Need 40-60 kkal/kg dietary energy and 1.2-1.5 g/ $\mathrm{kg}$ protein. If weight loss is greater than $1 \mathrm{~kg} /$ week or if diarrhea is greater than $600 \mathrm{~g} /$ day, TPN may need to be restarted. ${ }^{17,20}$

Third Postoperative Phase: 18-24 months, maximal adaptation with possible discontinuation of parenteral nutrition when intake of fluid is up to 7 L/daily and when energy intake is sufficient for desired weight goal. It is very easy to loose large amounts of water, minerals and vitamins through an ileostomy when diarrhea occurs which can quickly leads to dehydration. ${ }^{21}$ It is the best way to try weaning off parenteral nutrition without trophic factors; if this is unsuccessful, a recombinant human growth hormone regimen or investigational studies using other trophic factors should be attempted. ${ }^{22}$

Complete bowel adaptation begins as TF is tolerated and oral diet is slowly resumed (from 2 months to 1 year). Six small meals that are high carbohydrate and low fat may be tolerated $(60 \% \mathrm{CHO}, 20 \%$ protein, 20\%fat, with limit in MCT of $40 \mathrm{~g} /$ day). With no colon, the diet may be need to be $30-40 \%$ fat, $20 \%$ protein, and 40-50\% CHO; jejunostomy feeding may be needed, and oxalates need not be restricted. ${ }^{23} \mathrm{PN}$ reductions can be made by either decreasing the days of PN infusion per week or decreasing the PN infusion volume equally across all days of the week. ${ }^{24}$ 
Table 3. Food classification as degree of acidity or alkalinity

\begin{tabular}{|c|c|c|}
\hline Acid Ash Foods & Alkaline Ash Foods & Neutral Foods \\
\hline Most meats & Milk & Butter \\
\hline Breads \& cereals & Bananas & Coffee \\
\hline Cheese & Beans & Cream \\
\hline Corn & Beets & Honey \\
\hline Crackers & Greens & Salad oils \\
\hline Cranberries & Spinach & Syrups \\
\hline Eggs & Most fruits (including citrus fruits) & Tapioca \\
\hline Macaroni & Most vegetables & Tea \\
\hline \multicolumn{3}{|l|}{ Nuts } \\
\hline \multicolumn{3}{|l|}{ Pasta, Rice } \\
\hline \multicolumn{3}{|l|}{ Prunes, Plums } \\
\hline \multicolumn{3}{|l|}{ Fish } \\
\hline Poultry & & \\
\hline
\end{tabular}

Adequate zinc, potassium, liquid magnesium, oral calcium (600-1000 mg/day), manganese, iron, vitamin C, selenium, B-complex vitamins (esp. folic acid), and other nutrients may be needed as supplements. With antibiotic use, the patient will need extra vitamin K. Lactose-restricted and oxalaterestricted diets may be needed for an extended period of time. Rhubarb, spinach, beets, cocoa, and chocolate, sweet potatoes, strawberries, celery and peanuts are high in oxalate; nuts, and nut butters, berries, concord grapes, sweet potatoes and potatoes, and most vegetables should be consumed smaller amounts. Omiting alcoholic beverages and caffeine unless physician permits small quantities. Taking fluids between instead of with meals may be helpful in reducing dumping. With osmotic diarrhea, a reduction in simple carbohydrates and an increase in complex carbohydrates may be needed. ${ }^{17}$

c. Urostomy (Bladder Surgeries): The urinary system is a simple network with complex functions. It plays a role in fluid balance, electrolyte balance, acid-base balance and excretion of waste. To maintain healthy kidney function, drink sufficient fluids to keep the urine diluted. If urine color is darker than usual, it is an indication of concentrated urine which requires an increase in fluid intake. Certain foods and drugs can discolor the urine or produce a strong odor. Urine $\mathrm{pH}$ is defined as the fluid's degree of acidity or alkalinity. When the food we eat is burned in the body, it yields a mineral residue cal- led "ash." This ash can be either acidic or basic (alkaline) depending on whether the food that is "burned" contains mostly acidic or basic ions. Most fruits and vegetables actually give an alkalinized ash and tend to alkaline the urine. Meats and cereals will usually produce an acidic ash (Table 3).,10,25

\section{GENERAL HEALTHY EATING GUIDELINES IN STOMA PATIENTS}

a. Consuming a balanced diet to obtain necessary vitamins, minerals and calories needed for good health. Usually after the surgery, the patients start out with a low fibre/residue diet. The reason is that the surgery causes the bowel to swell. The swelling will reduce in 6 to 8 weeks. Thereafter the patients can resume regular diet.

b. Adding one new food at a time to observe their effects. Keeping the food consumption may be helpful.

c. The patients may need to take a multivitamin supplement during the first year of recovery from surgery.

d. Consuming a wide variety of food.

e. Eating at regular intervals. Skipping meals increase the incidence of stools and gas. Small frequent meals may be helpful.

f. Chewing the food thoroughly. Cutting up food into bite size pieces may also improve tolerance. 
g. Lactose intolerance is common. The patients may want to avoid dairy products for the first month if notice gas, bloating and diarrhea after ingestion of dairy products. It may be tried soymilk or low-lactose cow's milk..$^{10,25}$

\section{CONCLUSION}

In this article, it is suggested to consume a balanced diet with a wide variety of foods and take plenty of fluids in order to prevent food blockage. People with ostomies can have many different foods with few restrictions. Each food group provides a combination of key nutrients (minerals, vitamins, and etc.) for optimum body function. It is recommended to be followed up all fluid and dietary restrictions set out by the doctors, dietitians and/or nutrition nurses.

\section{REFERENCES}

1. Burch J. The pre- and postoperative nursing care for patients with a stoma. Br J Nurs 14: 310-318, 2005.

2. Fullham J. Providing dietary advice for the individual with a stoma. Br J Nurs 17: 22-27, 2008.

3. Boby Brewer ET. Diet and nutrition guide. In: Judith Ehlers-Crim, United Ostomy Association (UAO) Inc. 1st ed. USA, 2002: 1-18.

4. Cima RR. Pemberton JH. lleostomy, colostomy, and pouches. In: Feldman M. Friedman LS, Brandt LJ. Sleisenger \& Fordtran's Gastrointestinal and Liver Disease. 8th ed. Pa: Saunders Elsevier, Philadelphia, 2006: 5-110.

5. Fry RD, Mahmoud N, Maron DJ, et al. Colon and rectum. In: Townsend Jr. CM, Beauchamp RD, Evers BM, Mattox KL. Sabiston Textbook of Surgery. 18th ed. Pa: Saunders Elsevier, Philadelphia, 2008: 25-50.

6. Pang AS. A new feeding tube which is secure and easy to change. Singapore Med J 50: 740-742, 2009.

7. Zhou T. Early removing gastrointestinal decompression and early oral feeding improve patients' rehabilitation after colerectostomy. World J Gastroenterol 2: 2459, 2006.

8. Black PK. Colostomy. Prof Nurse 13: 851-857, 1998.

9. Bradshaw E, Collins B. Managing a colostomy or ileostomy in community nursing practice. $\mathrm{Br} J$ Community Nurs 13: 514-518, 2008.

10. Taylor C, Morgan L. Quality of life following reversal of temporary stoma after rectal cancer treatment. Eur J Oncol Nursing 10: 1-8, 2010.

11. Burch J. Nutrition for people with stomas. 2: An overview of dietary advice. Nurs Times 104: 26-27, 2008.

12. Burch J. Nutrition and the ostomate: input, output and absorption. Br J Community Nurs 11: 349-351, 2006.
13. Floruta CV. Dietary Choices of People with Ostomies. J Wound Ostomy Continence Nurs 28: 28-31, 2001.

14. Tilg H. Short bowel syndrome: searching for the proper diet. Eur J Gastroenterol Hepatol 20: 1061-1063, 2008.

15. Bradshaw E, Collins B. Managing a colostomy or ileostomy in community nursing practice. $\mathrm{Br} \mathrm{J}$ Community Nurs 13: 514-518, 2008.

16. Black P. Practical stoma care. Nurs Stand 14: 47-53, 2000

17. Khatri VP, Asensio JA, eds. Subtotal colectomy/panproctocolectomy and j-pouch reconstruction. Operative Surgery Manual. 1st ed. Pa: Saunders Elsevier, Philadelphia, 2003: 20-35.

18. Tsao SK, Baker M, Nightingale JM. High-output stoma after small-bowel resections for Crohn's disease. Nat Clin Pract Gastroenterol Hepatol 2: 604-608, 2005.

19. Zarkovi M, Milievi M. Enteral nutrition in patients with ileostomies and jejunostomies. Acta Chir lugosl 42: 17-20, 1995

20. Johnson M. Management of short bowel syndrome-a review. Support Line 22: 11-13, 2006.

21. Crenn P. Morin MC, Joly F, et al. Net digestive absorption and adaptive hyperphagia in adult short bowel patients. Gut 53: 1279-1286, 2004.

22. Striger E, DiBaise JK, Messing B, et al. Indications and recommendations for the use of recombinant human growth hormone in adults short bowel syndrome patients dependent on parenteral nutrition. J Clin Gastroenterol 40(Suppl 2): 99-106, 2006.

23. Johnson M. Management of short bowel syndrome-a review. Support Line 22: 11-23, 2002.

24. Dibasie JK, Matarese LE, Messing B, et al. Strategies for parenteral nutrition weaning in adult patients with short bowel syndrome. J Clin Gastroenterol 40 (Suppl 2): 94- 98, 2006.

25. Salvadalena G. Incidence of complications of the stoma and peristomal skin among individuals with colostomy, ileostomy, and urostomy: a systematic review. J Wound Ostomy Continence Nurs 35: 596607,2008

\section{Correspondence}

Gamze AKBULUT

Gazi Üniversitesi Sağlık Bilimleri Fakültesi

Beslenme ve Diyetetik Bölümü

06100 Beşevler, Ankara / TURKEY

Tel: (+90.312) 2162639

Fax: (+90.312) 2162636

e-mail: dytgamzea@gmail.com gakbulut@gazi.edu.tr 